Vol. 3, No. 2, 2020

\author{
Andrii Galstyan $^{1,2}$, A. Bushuiev ${ }^{1}$, K. Skorokhod ${ }^{2}$, A. Krasylnikova ${ }^{1}$, M. Zhurba ${ }^{1}$ \\ ${ }^{1}$ SE "Luhansk State Medical University" \\ ${ }^{2}$ Institute of Chemical Technologies of Volodymyr Dahl East Ukrainian National University \\ aggaalst@gmail.com
}

\title{
KINETICS AND OXIDATION PRODUCTS OF ETHYLBENZENE AND ITS SUBSTITUTED BY OZONE IN ACETIC ACID
}

https://doi.org/10.23939/ctas2020.02.191

Based on the obtained kinetic regularities and the mixture of the products of the reaction of ethylbenzene oxidation with ozone in acetic acid, the scientific bases of the technology of synthesis of acetophenone was developed. It is shown that in the ozonation conditions, in the presence of manganese (II) acetate, it is possible to direct oxidation mainly through the ethyl group of the substrate with the formation of aromatic products. The technological parameters are studied and the optimal conditions for the process realization are ascertained. The obtained experimental and theoretical results allowed us to propose a new low-temperature low-waste method of acetophenone production, which ensures the efficiency of the process due to the mild oxidation conditions $(288 \mathrm{~K}$, atmospheric pressure) and the reduction of toxic waste. The technology can be an alternative to existing methods of the synthesis of aromatic ketones.

Key words: ethylbenzene, acetophenone, catalyst, kinetics, oxidation, ozone.

\section{Introduction}

Today, the leading place among oxidants is taken by molecular oxygen. there are numerous industrial methods of synthesis of aromatic products occur with its participation[1, 2]. However, sometimes the use of oxygen is rejected due to harsh process conditions. In these cases, multi-stage processes or expensive and deficient mineral oxidants are often used that leads to environmental pollution $[3,4]$. The latest scientific studies in the range of benzene show that these problems can be successfully solved with the help of ozone technologies [5]. The described technologies are characterized by high selectivity, mild reaction conditions and simplified technological equipment, but they relate to the processes of ozone oxidation only in a homologous range of toluene and its substituted [58]. In this connection, studies of the reaction of ozone with ethylbenzene and its substituted, aimed at further development of low-waste oxidation technologies and expansion of understanding of the reaction of ozone with arenes in ethylbenzene range, can be of particular interest. The solution of this problem is of great practical importance, since acetophenone, a product of incomplete oxidation of ethylbenzene, is an important raw material for the production of fragrances in perfumery [9], and, possessing a hypnotic effect, is used for the manufacture of sedative drugs [10].

In the industry, acetophenone is produced by the Friedel-Crafts reaction based on benzene and acetyl chloride or acetate anhydride in the presence of $\mathrm{AlCl}_{3}$ [11], or by liquid-phase oxidation of ethylbenzene with oxygen at 388-393 K (catalyst benzoate $\mathrm{Co}, \mathrm{Cu}, \mathrm{Mn}, \mathrm{Ni}, \mathrm{Pb}$ or $\mathrm{Fe}$ ) [12]. However, the analysis of these methods shows that most of them have no future due to the technological complexity, harsh synthesis conditions and low selectivity. Therefore, the development of the basics of the lowwaste, low-temperature technology for the synthesis of acetophenone by oxidation of ethylbenzene with ozone in the solution of acetic acid is an urgent task.

\section{Experimental}

For the experiments the acetic acid of the "Sigma" firm of qualification "puriss."; ethylbenzene, 1-bromo-4-ethylbenzene, acetophenone of "Acros Organics" firm of qualification "puriss."; acetates of the metals of qualification "puriss." were used.

Acetophenone synthesis. $200 \mathrm{ml}$ of glacial acetic acid, $8.5 \mathrm{~g}\left(0.4 \mathrm{~mol} \cdot 1^{-1}\right)$ of ethylbenzene and $2.1 \mathrm{~g}\left(0.04 \mathrm{~mol} \cdot \mathrm{l}^{-1}\right)$ of 4 aqueous manganese (II) acetate are loaded into a $500 \mathrm{ml}$ perforated bottom 


\section{A. Galstyan, A. Bushuiev, K. Skorokhod, A. Krasylnikova, M. Zhurba}

reactor with a temperature of $293 \mathrm{~K}$. The resulting solution is thermostated at $288 \mathrm{~K}$ and fed through it ozone-air mixture with ozone concentration of $1.12 \% \mathrm{vol}$ at a rate of $601 \cdot \mathrm{h}^{-1}$. The average degree of ozone absorption during oxidation is $83.3 \%$. After $9 \mathrm{~h}$ of oxidation, the sample is taken for analysis on the absence of substrate, when the results of the analysis are positive the introduction of the ozone-air mixture is stopped, the reaction mass is treated with oxalic acid for discolouration of the solution, and then under a vacuum of $100 \mathrm{mmHg}$ and the temperature of $333 \mathrm{~K} 90 \%$ of the original volume of acetic acid is distilled off, $45 \mathrm{ml}$ of water is added to the residue, the resulting emulsion is shaken for half an hour in a separating funnel, then is settled to separate. The bottom layer containing the aqueous solution of acetic acid and the catalyst is taken and direct for the regeneration of the catalyst. The organic layer containing acetophenone and 1-phenylethyl acetate in the ratio 8: 1 is subjected to freezing, during which $8.3 \mathrm{~g}$ of acetophenone are obtained, $\mathrm{T}_{\text {boil }}=475-477 \mathrm{~K}$. The liquid residue, which contains the rest of acetophenone and 1-phenylethyl acetate, is added to 9 the same residues from previous operations, after which the resulting mixture is dissolved in $200 \mathrm{ml}$ of acetic acid and oxidized at $298 \mathrm{~K}$ for two hours. In the process of oxidation, acylated alcohol is converted to acetophenone. From the resulting solution, acetic acid is distilled off at the temperature of $333 \mathrm{~K}$ and a vacuum of $100 \mathrm{mmHg}$. Acetophenone with $\mathrm{T}_{\text {boil }}=474-475 \mathrm{~K}$ and the mass of $1.26 \mathrm{~g}$ is identified in the residue. The total yield of acetophenone is $87.7 \%$.

\section{Materials and methods of research}

The ozone concentration in the gas phase was determined by spectrophotometric method on SF-46 spectrophotometer. The concentration of ethylbenzene and its derivatives in the solution was determined by gas-liquid chromatography on the chromatograph with the flame-ionization detector on $1 \mathrm{~m}$ long and $3.5 \mathrm{~mm}$ column diameter, filled with the carrier - "INERTONSuper" (0.16-0.2 mm), with a stationary phase "FFAP" applied to it in the amount of $5 \%$ by weight of the carrier under the following conditions: evaporator temperature $-503-533 \mathrm{~K}$; the velocity of gas-carrier (nitrogen) is $2.0 \mathrm{l} \cdot \mathrm{h}^{-1}$; hydrogen velocity is $1.8 \mathrm{l} \cdot \mathrm{h}^{-1}$; airspeed is $18 \mathrm{l} \cdot \mathrm{h}^{-1}$. Thermostating was carried out in the temperature range $363-448 \mathrm{~K}$, the temperature was raised by the program $-8{ }^{\circ} \mathrm{C} / \mathrm{min}$. The concentration of peroxides was determined by a known iodometric method [13].

\section{Research results and their discussion}

During the ethylbenzene oxidation with ozone in glacial acetic acid at $288 \mathrm{~K}$, the reaction runs mainly via the benzene ring with the formation of ozonides (64\%) (Fig. 1), which are further transformed into aliphatic peroxide products (Scheme 1). Among the aromatic reaction products, 1-phenylethan-1-ol was identified in the early stages, and acetophenone $(30 \%)$ at complete oxidation of the substrate (Fig. 1, Sch. 2). Under the conditions of experiments, acetophenone is also an intermediate reaction product. As can be seen from Fig. 3.1, after 150 minutes of oxidation, its concentration in the solution decreases gradually. However, according to the literature data [13] the expected benzoic acid, which is formed during the acetophenone oxidation, was found in the amount of $4 \%$ of the total amount of reaction products in our case. However, the $\mathrm{CO}_{2}$ emission of $0.2 \mathrm{~mol}$ per $1 \mathrm{~mol}$ of ethylbenzene has been recorded, which can indicate the oxidative decarboxylation of the reaction products.

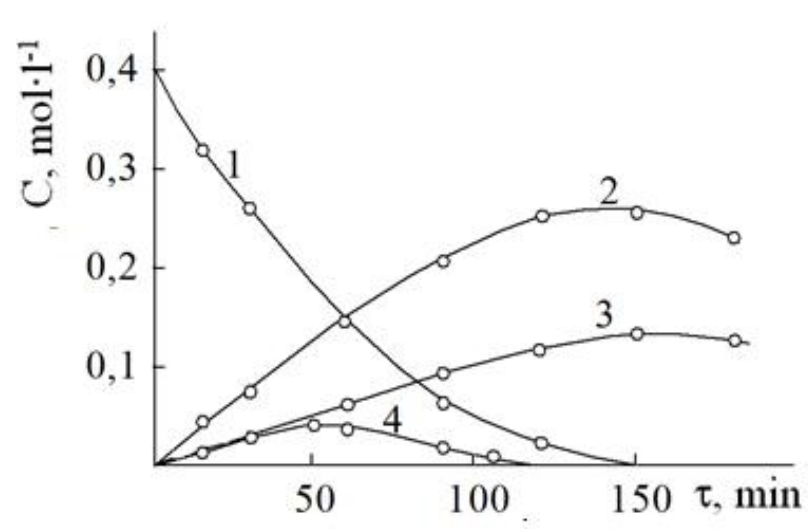

Fig. 1. Kinetics of ethylbenzene oxidation by ozone-air mixture in acetic acid; $T=288 \mathrm{~K} ;\left[\mathrm{ArCH}_{2} \mathrm{CH}_{3}\right]_{o}=0,4 ;\left[\mathrm{O}_{3}\right]_{o}=5,2 \cdot 10^{-4} \mathrm{~mol} \cdot \mathrm{l}^{-1}$; $V_{l}=0,01 l ; \omega=30 l \cdot h^{-1}$; Changes in the concentration of ethylbenzene (1), ozonides (2), acetophenone (3), 1-phenylethan-1-ol (4)

$\alpha$-Phenylethylhydroperoxide is not identified in the experiments. However, in the reaction mass, the peroxide products of degradation of the benzene ring (ozonolysis) (Fig. 1, Sch. 2), which represent a light yellow colour liquid with characteristic solubility in acetic acid and tetrachloroethane, accumulate to a considerable degree. They react with potassium iodide at high velocity, and in 1 hour there forms the amount of molecular iodine that corresponds to one hydroperoxide group (Table 1). After 24 hours of exposure to 
the test solution, the results of the analysis are almost unchanged. These data do not contradict the literature [14], in which namely hydroperoxide groups react quickly with potassium iodide (usually within an hour), and the recovery of dialkyl peroxide groups is completed within 20-24 hours.

The analysis of the IR spectra of peroxides showed the absence of bands typical for the benzene ring, but the presence of bands typical for the $\mathrm{C}=\mathrm{O}$ groups $\left(1705-1730 \mathrm{~cm}^{-1}\right)$ and the hydroperoxide groups $\left(760,1050,1300 \mathrm{~cm}^{-1}\right)$. These facts, as well as the stoichiometric coefficient of ozone, which at the temperature of $288 \mathrm{~K}$ is 2 , are additional confirmation of this assumption, and also indicate that these hydroperoxides are formed due to the ozonides and are linear structure monomers.

According to the accepted Criegee's reaction of the ozonolysis of the aromatic ring [15], the oxidation of ethylbenzene can occur in the following ways:

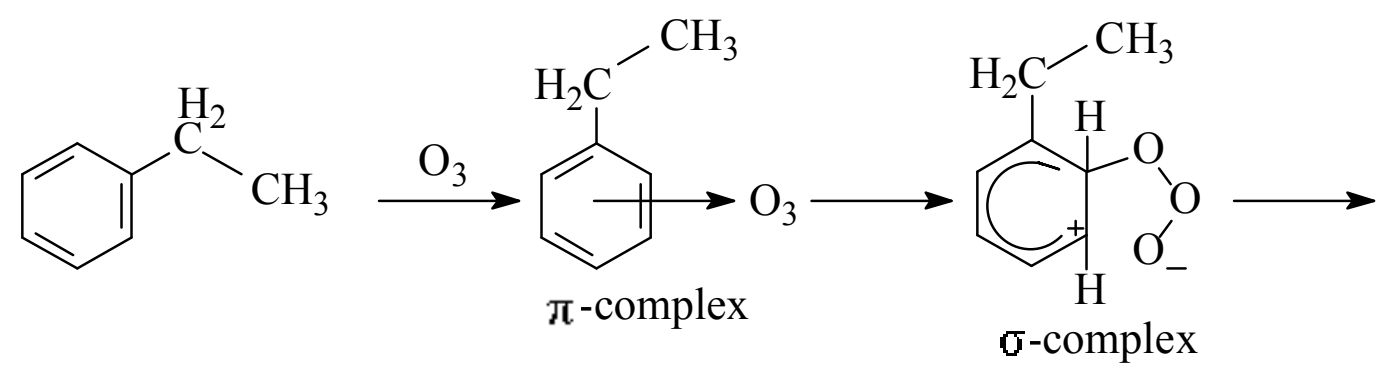<smiles>CCC(C=O)=CC=CC=[O+][O-]</smiles><smiles>CC/C(C=O)=C\C=C\C(O)OC(=O)O</smiles>

Scheme 1

The formation of aromatic products of ethylbenzene ozonation corresponds to the scheme of the transformation of the ethyl group, in which peroxyl radical recombines with the formation of alcohol and ketone [16] with subsequent conversion into products of oxidation and oxidative decarboxylation:

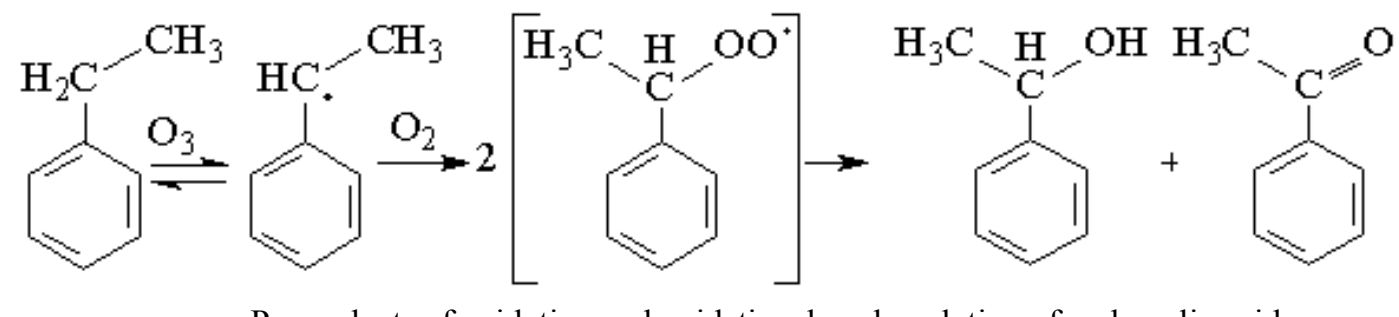

$\mathrm{P}$-products of oxidation and oxidative decarboxylation of carboxylic acids. 
The effect of the exposure time a mixture of solutions of the analyzed ethylbenzene peroxides with potassium iodide on the analysis results (oxidation conditions, Fig. 1)

\begin{tabular}{|c|c|c|}
\hline \multirow{2}{*}{ Oxidation time, min. } & \multicolumn{2}{|c|}{${\text { Concentration of peroxides, } \mathrm{mol} \cdot \mathrm{l}^{-1}}^{-1}$} \\
\cline { 2 - 3 } & After hours of exposure to the test solution & $\begin{array}{c}\text { After } 24 \text { hours of exposure to the test } \\
\text { solution }\end{array}$ \\
\hline 15 & 0.050 & 0.050 \\
30 & 0.075 & 0.075 \\
60 & 0.140 & 0.150 \\
90 & 0.205 & 0.225 \\
120 & 0.260 & 0.290 \\
150 & 0.235 & 0.255 \\
\hline
\end{tabular}

The consumption of ozone in reaction with ethylbenzene coincides well with the considered schemes. While oxidation to acetophenone (Sch. 2), 4 electrons are displaced during the reaction, and when $\mathrm{O}_{3}$ is reduced only 2 electrons are displaced, that is 2 mol of ozone is consumed per $1 \mathrm{~mol}$ of ethylbenzene, and $0.68 \mathrm{~mol}$ of ozone is consumed by $0.34 \mathrm{~mol}$. According to Scheme 1, the formation of hydroperoxide requires $2 \mathrm{~mol}$ of ozone, and $1.32 \mathrm{~mol}^{\circ} \mathrm{O}_{3}$ requires for $0.66 \mathrm{~mol}$, from which the calculated amount of ozone is $0.68+1.32=2 \mathrm{~mol}$ of ozone.

With the increasing temperature in the studied interval $(288-343 \mathrm{~K})$, there is an increase in the consumption of ozone (up to $4.5 \mathrm{~mol}$ ), the initial oxidation velocities of ethylbenzene and the accumulation of reaction products triply, while the maximum concentrations of both alcohol and ketone reduce gradually. It is typical that acetophenone is sufficiently resistant to ozone in the temperature range from 288 to $313 \mathrm{~K}$ (Fig. 2), but further increase in temperature to $343 \mathrm{~K}$ leads to a decrease in selectivity for acetophenone almost twice. Similar temperature dependencies are an additional argument in favour of the fact that 1-phenylethan-1-ol and acetophenone are intermediate products of ethylbenzene oxidation according to Scheme 2 .
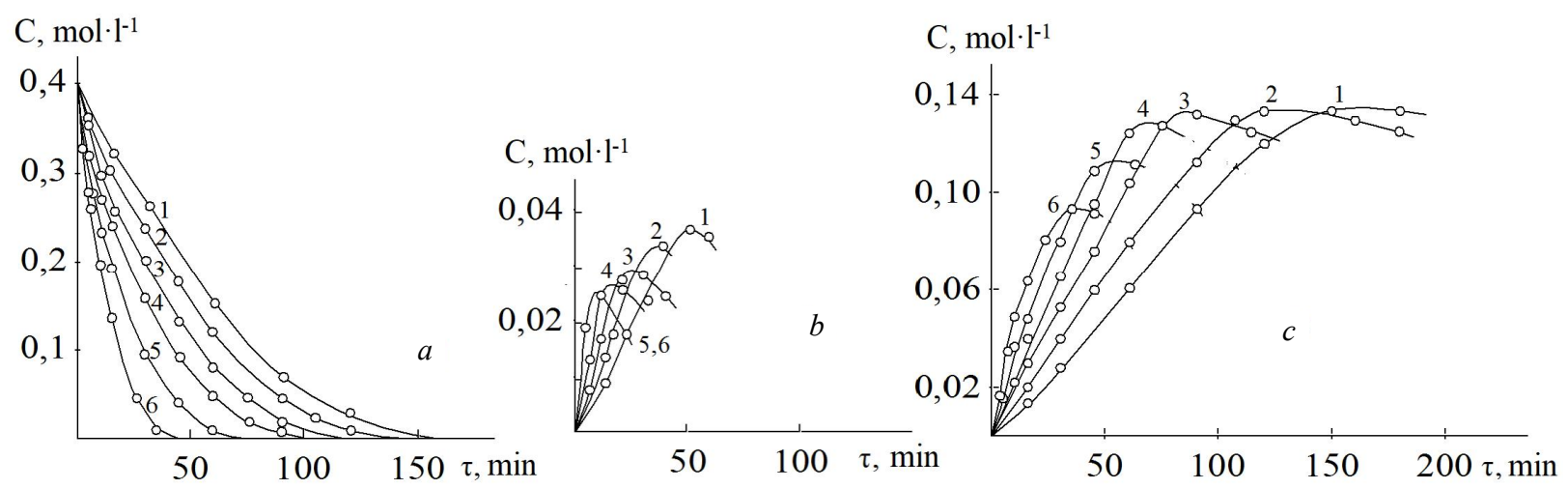

Fig. 2. Effect of temperature on the kinetics of oxidation of ethylbenzene with ozone-air mixture in acetic acid: consumption of ethylbenzene (a); accumulation of 1-phenylethan-1-ol (b), acetophenone (c). $\left.\left[\mathrm{O}_{3}\right]_{o}=5.2 \cdot 10^{-4}, \mathrm{ArCH}_{2} \mathrm{CH}_{3}\right]_{o}=0.4 \mathrm{~mol} \cdot l^{-1}, \omega=30 \mathrm{l} \cdot \mathrm{h}^{-1} 1, \mathrm{~V}_{\mathrm{r} .}=10 \mathrm{ml}$. Temperature: 288 (1), 293 (2), 303 (3), 313 (4), 323 (5), $343 K$ (6)

In the presence of the catalyst manganese (II) acetate the selectivities of oxidation of ethylbenzene on the side chain and the output of acetophenone increase significantly (Table 1). It becomes possible due to two-stage oxidation (1-3):

$$
\begin{gathered}
\mathrm{Mn}(\mathrm{II})+\mathrm{O}_{3}+2 \mathrm{H}^{+} \rightarrow \mathrm{Mn}(\mathrm{IV})+\mathrm{O}_{2}+\mathrm{H}_{2} \mathrm{O} \\
\mathrm{ArCH}_{2} \mathrm{CH}_{3}+\mathrm{Mn}(\mathrm{IV}) \rightarrow \mathrm{ArC}^{*} \mathrm{HCH}_{3}+\mathrm{Mn}(\mathrm{III})+\mathrm{H}^{+} \\
\mathrm{ArCH}_{2} \mathrm{CH}_{3}+\mathrm{Mn}(\mathrm{III}) \rightarrow \mathrm{ArC}^{\circ} \mathrm{HCH}_{3}+\mathrm{Mn}(\mathrm{II})+\mathrm{H}^{+}
\end{gathered}
$$




\section{Kinetics and oxidation products of ethylbenzene and its substituted by ozone in acetic acid}

In these conditions, ozone reacts not with ethylbenzene $\left(\mathrm{k}=0.41(\mathrm{~mol} \cdot \mathrm{s})^{-1}\right)$, but with metal $\left(\mathrm{k}=1,8 \cdot 10^{3} 1(\mathrm{~mol} \cdot \mathrm{s})^{-1}\right)$ with the formation of the oxidized form of manganese (1), which then involves the substrate to the oxidation according to the ethyl group at high speed $(2,3)$.
The introduction of a bromine atom into the ethylbenzene molecule contributes to the increase in the yield of the corresponding acetophenone up to $92 \%$ (Table 2), that satisfies completely the current understanding of the effect of the substituents nature on the reactivity of the compound [5].

Table 2

Selectivity of catalytic oxidation of alkylbenzenes by ozone at $288 \mathrm{~K}$ in acetic acid. $\left[\mathrm{ArC}_{2} \mathrm{H}_{5}\right]_{0}=0.4 ;\left[\mathrm{O}_{3}\right]_{0}=5.2 \cdot 10^{-4} ;\left[\mathrm{Mn}(\mathrm{OAc})_{2}\right]_{0}=0.04 \mathrm{~mol} \cdot \mathrm{I}^{-1}$

\begin{tabular}{|c|c|c|c|}
\hline \multirow{2}{*}{ Compound } & \multicolumn{2}{|c|}{ The concentration of the corresponding reaction products, mol/1 } & $\begin{array}{c}\text { The total yield of the } \\
\text { reaction products by } \\
\text { ethyl group, } \%\end{array}$ \\
\cline { 2 - 4 } & acetophenone & 1-phenylethyl acetate & 87.7 \\
\hline Ethylbenzene & 76.5 & 11.2 & 97.6 \\
\hline
\end{tabular}

As can be seen from Table 2, the main products with the preserved aromatic structure are the corresponding acetophenone and 1-phenylethyl acetate. 1-Phenylethan-1-ol and trace amounts of benzaldehyde $\left(\mathrm{C} \leq 10^{-4} \mathrm{~mol} \cdot \mathrm{l}^{-1}\right)$ were identified as intermediate products of ethylbenzene oxidation. After exhaustive oxidation of ethylbenzene, up to $4 \%$ of benzoic acids were identified.

According to the received and literature data $[5,14,16-18]$, the catalytic ozonation of ethylbenzene occurs by a non-chain mechanism according to the reaction scheme (1-5).

The phenylbenzyl radical obtained by reaction (3) is transformed rapidly in reaction with oxygen $\left(k=108 \mathrm{l} \cdot(\mathrm{mol} \cdot \mathrm{s})^{-1}\right.$ [14] forming a peroxide radical, which further recombines with the corresponding alcohol and ketone [16].

According to the results of kinetic studies, it was shown that 1-phenylethan-1-ol is the major intermediate product under non-catalytic ozonation. However, in the presence of manganese (IV) acetate, 1-phenylethyl acetate accumulates with it, that is acylated alcohol is formed only in the presence of a catalyst. In this regard, we assume that acylation can occur through the formation of the $\mathrm{ArC}+\mathrm{HCH}_{3}$ cation by reactions (6-8).

Non-chain oxidation of ethylbenzene with ozone is indicated by the obtained kinetic data: first, ozone should be fed to the system continuously, and its termination leads to stopping the process. It additionally indicates that under conditions when the limiting stage of the selective oxidation of ethylbenzene is the reaction $(2,3)$ of formation of Mn (IV) occur by the reaction with ozone (1), and the chain extension reactions [16], in which Mn (IV) can also occur, are minor; and secondly, $2.3 \mathrm{~mol}$ of ozone is consumed per $1 \mathrm{~mol}$ of ethylbenzene, that is the theoretically required amount. This ratio of $\mathrm{ArCH}_{2} \mathrm{CH}_{3}$ to $\mathrm{O}_{3}$ also indicates that the same chain-extension reactions do not play a significant role. If it had been to the contrary, ozone would have required only as an initiator of oxidation. That is, it should be involved only at the beginning of the reaction, or in small quantities throughout the reaction.

The velocity of oxidation and the mixture of the reaction products are significantly affected by the reaction temperature (Fig. 3, Table 3). With the increase in temperature from 288 to $343 \mathrm{~K}$, the initial oxidation velocity of ethylbenzene increases almost twice with the increase in the velocity of accumulation of its oxidation products on the side chain of 1-phenylethan-1-ol and 1-phenylethyl acetate, and the velocity of accumulation of acetophenone decrease gradually.

In contrast to the velocity, the selectivity of side-chain oxidation, both for the products outlined and as a whole, tends to decrease.

The obtained temperature dependences can be explained based on the data in Table 4. As can be seen, the activation energy of ethylbenzene is almost twice as high as the activation energy of alcohol and its acetate. With this ratio, the velocity of oxidation of the intermediate products increases with temperature more slowly than the velocity of their accumulation and, as a result, the increase in the velocity of accumulation of the product is accompanied by a certain decrease in selectivity for the substance.

The simultaneous decrease in the velocity of acetophenone oxidation and its selectivity is explained by the fact that the activation energy of the acetophenone oxidation reaction is slightly higher than the activation energy of the ethylbenzene oxidation reaction. 
A. Galstyan, A. Bushuiev, K. Skorokhod, A. Krasylnikova, M. Zhurba
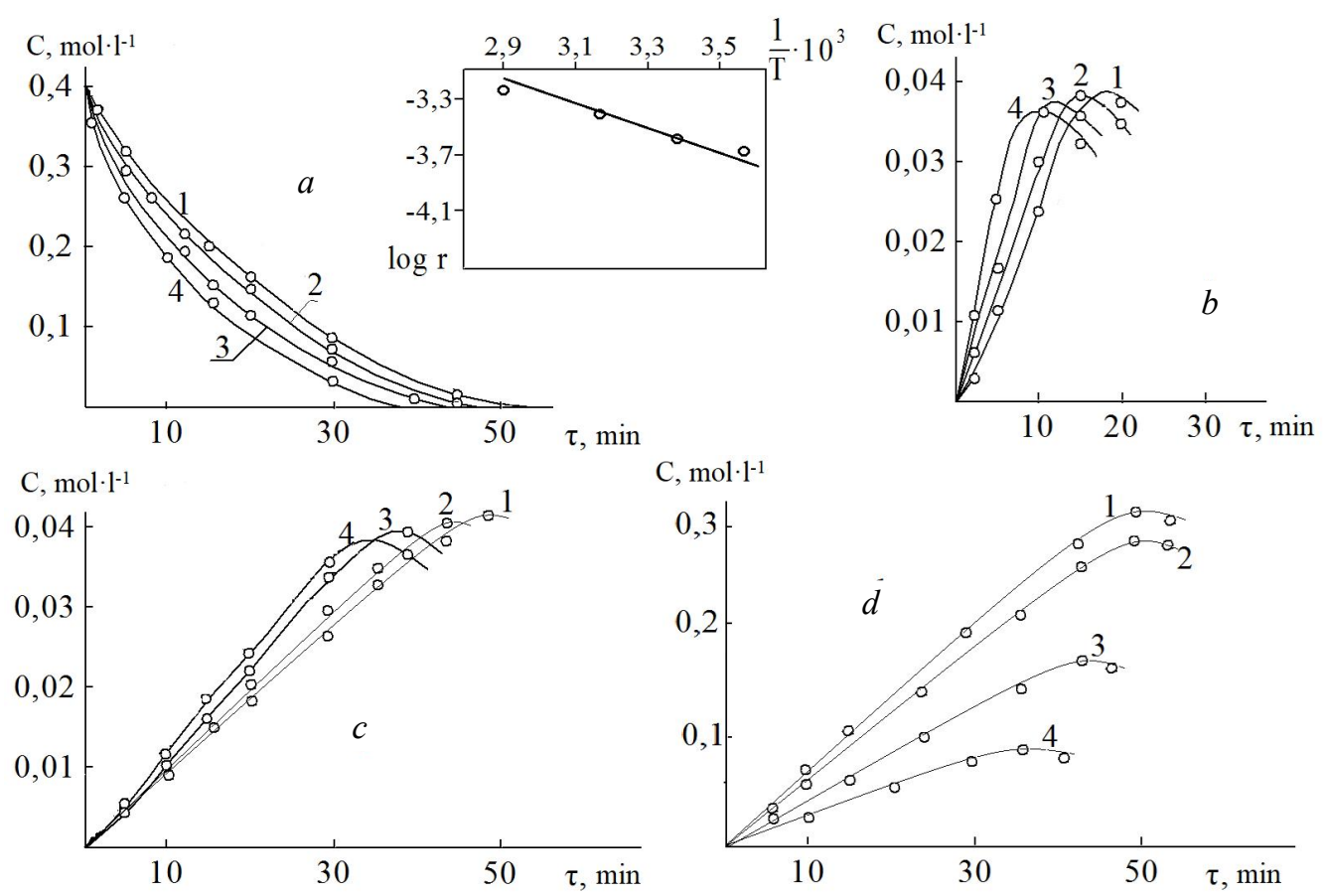

Fig. 3. The effect of temperature on kinetics: consumption of ethylbenzene (a) in reaction with ozone in acetic acid in the presence of manganese (II) acetate; accumulation of 1-phenylethan-1-ol (b), 1-phenylethyl acetate (c) and acetophenone (d); reaction velocity dependence on temperature (e); $\left[\mathrm{ArCH}_{2} \mathrm{CH}_{3}\right]_{0}=0.4 \mathrm{~mol} \cdot \mathrm{l}^{-1} ;\left[\mathrm{O}_{3}\right]_{0}=5.2 \cdot 10^{-4} ;\left[\mathrm{Mn}(\mathrm{OAc})_{2}\right]_{0}=0.04 \mathrm{~mol} \cdot \mathrm{l}^{-1}$; $V_{g}=8.3 \cdot 10^{-3} l \cdot s^{-1}, V_{l}=0 ., 01 l . T=288(1) ; 303$ (2); $318(3) ; 343$ (4) $\mathrm{K}$

Table 3

The effect of temperature on the yield of ethylbenzene oxidation products.

$\left[\mathrm{ArCH}_{2} \mathrm{CH}_{3}\right]_{0}=0.4 ;\left[\mathrm{O}_{3}\right]_{0}=5.2 \cdot 10^{-4} ;\left[\mathrm{Mn}(\mathrm{OAc})_{2}\right]_{0}=0,04 \mathrm{~mol} \cdot \mathrm{l}^{-1} \cdot \mathrm{V}_{\mathrm{g}}=8.3 \cdot 10^{-3} \mathrm{l} \cdot \mathrm{s}^{-1}, \mathrm{~V}_{\mathrm{r} . \mathrm{m} .}=0.01 \mathrm{I}$

\begin{tabular}{|c|c|c|c|}
\hline \multirow{2}{*}{$\mathrm{T}, \mathrm{K}$} & \multicolumn{2}{|c|}{ Yield, \% } & \multirow{2}{*}{$\begin{array}{c}\text { The selectivity of the oxidation } \\
\text { according to the ethyl group }\end{array}$} \\
\cline { 2 - 3 } & acetophenone & 1-phenylethyl acetate & 87.7 \\
288 & 76.5 & 11.2 & 74.7 \\
303 & 65.0 & 9.7 & 47.1 \\
343 & 37.5 & 9.6 & 29.2 \\
\hline
\end{tabular}

The effective activation energy of the catalytic oxidation process of ethylbenzene $\left(34.4 \mathrm{~kJ} \cdot \mathrm{mol}^{-1}\right)$ obtained from the graphical data (Fig. 3 a,e) correlates well with the data from the activation energy of the reaction of ethylbenzene with Mn (IV) (Table 4). This indicates that the reactions $(2,3)$ are limiting.

Ethylbenzene oxidation velocity increases markedly with the increase of ozone concentration in the system. This dependence on the concentration of ozone is a consequence of the increase of the velocity of formation of the oxidized form of the catalyst according to the reaction scheme (1). In the testing concentration range for ozone $\left(1 \cdot 10^{-4}-7.7 \cdot 10^{-4} \mathrm{~mol} \cdot \mathrm{l}^{-1}\right)$ the velocity of oxidation of the accumulated reaction products increases more than twice (Fig. 4). It's typical of these conditions that almost all reaction products are intermediate. But due to the different reactivity in the reactions with ozone and Mn (IV), their concentration changes over time occur in different ways. 1Phenylethan-1-ol accumulates quickly and is also quickly consumed and is not present in the system at the time of maximum acetophenone concentration. 1Phenylethyl acetate accumulates and consumes more slowly, due to this at $\left[\mathrm{Mn}(\mathrm{OAc})_{2}\right]_{0}=0.04 \mathrm{~mol} \cdot \mathrm{l}^{-1}$ at the moment of maximum acetophenone concentration its content reaches $11.2 \%$ in the reaction products. Acetophenone, as the most resistant to oxidation, is the main product formed in the system, but it is oxidized at a certain velocity with the destruction of the benzene ring. The selectivity of acetophenone oxidation remains almost unchanged at a predetermined concentration interval for ozone. 
Kinetic parameters of the reactions of ethylbenzene and its derivatives with Mn (IV) in acetic acid. $\left[\mathrm{Mn}(\mathrm{OAc})_{2}\right]_{0}=0.04 ;[\mathrm{ArH}]_{0}=0.4 \mathrm{~mol} \cdot \mathrm{l}^{-1}$

\begin{tabular}{|c|c|c|c|c|c|c|}
\hline Compound & $\mathrm{T}, \mathrm{K}$ & $1 / \mathrm{T} \cdot 10^{3}$ & $\mathrm{k}^{*}, 1(\mathrm{~mol} \cdot \mathrm{s})^{-1}$ & lgk & $\mathrm{E}, \mathrm{kJ} \cdot \mathrm{mol}^{-1}$ & $\mathrm{~A}, 1(\mathrm{~mol} \cdot \mathrm{s})^{-1}$ \\
\hline \multirow{3}{*}{ ethylbenzene } & 288 & 3.47 & 0.012 & -1.94 & & \\
& 303 & 3.30 & 0.029 & -1.55 & $32.8 \pm 2.7$ & $(1.13 \pm 0.08) \cdot 10^{4}$ \\
& 323 & 3.10 & 0.056 & -1.25 & & \\
& 343 & 2.91 & 0.096 & -1.02 & & \\
1-phenylethan-1-ol & 283 & 3.53 & 0.029 & -1.54 & & \\
& 288 & 3.47 & 0.033 & -1.48 & & \\
& 303 & 3.30 & 0.052 & -1.28 & $19.2 \pm 1.8$ & \\
& 323 & 3.10 & 0.080 & -1.10 & & \\
& 343 & 2.91 & 0.120 & -0.92 & & \\
& 283 & 3.53 & 0.0048 & -2.32 & & \\
& 288 & 3.47 & 0.0051 & -2.30 & & \\
& 303 & 3.30 & 0.0083 & -2.08 & & \\
& 323 & 3.10 & 0.0158 & -1.80 & & \\
& 283 & 3.53 & 0.0025 & -2.60 & & \\
& 288 & 3.47 & 0.0028 & -2.55 & & \\
& 303 & 3.30 & 0.0060 & -2.22 & $37.8 \pm 2.8$ & $(1.60 \pm 0.08) \cdot 10^{4}$ \\
& 323 & 3.10 & 0.0110 & -1.96 & & \\
\end{tabular}

* - effective velocity constants.
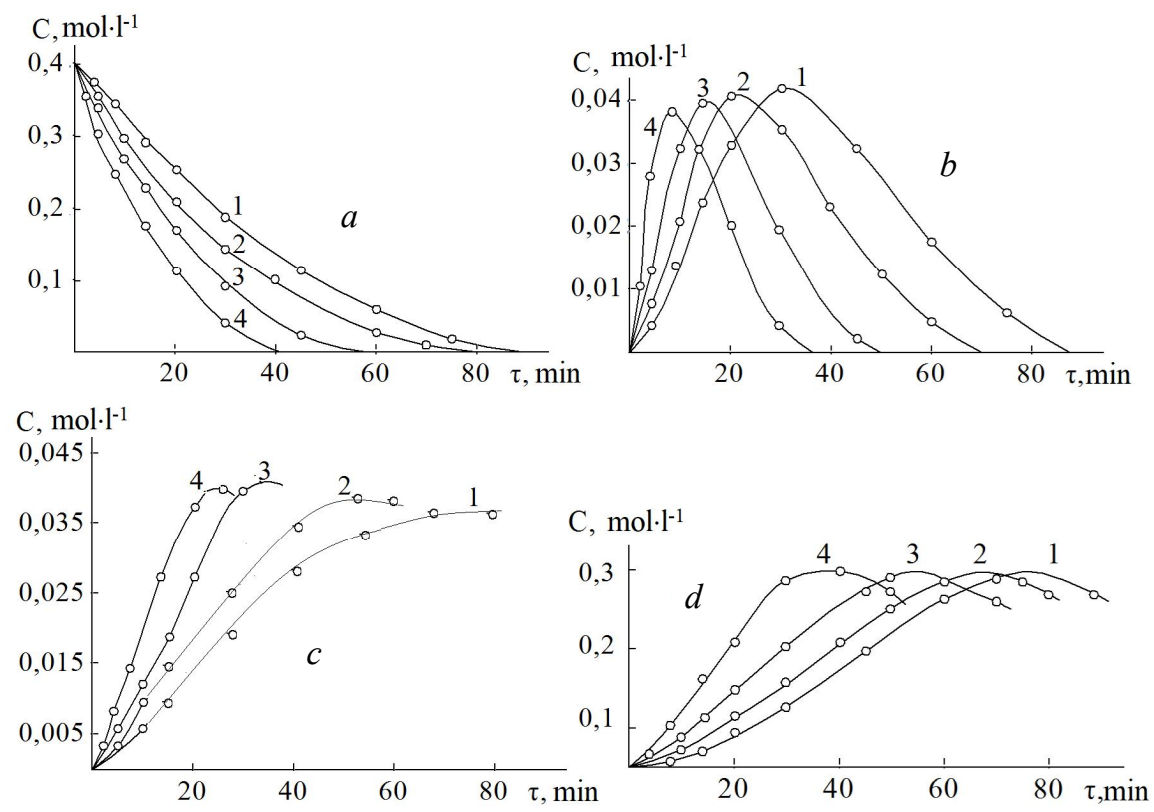

Fig. 4. Kinetics of ethylbenzene oxidation (a), accumulation of 1-phenylethan-1-ol (b), of 1-phenylethyl acetate (c), of acetophenone (d) when ozone concentration changes in the ozone-air mixture. $\left[\mathrm{O}_{3}\right]_{0}=1.0 \cdot 10^{-4}(1), 3.0 \cdot 10^{-4}(2), 5.2 \cdot 10^{-4}(3)$, $7.7 \cdot 10^{-4}(4) \mathrm{mol} \cdot \mathrm{l}^{-1} . \mathrm{T}=288 \mathrm{~K},\left[\mathrm{ArCH}_{2} \mathrm{CH}_{3}\right]_{0}=0.4,\left[\mathrm{Mn}(\mathrm{OAc})_{2}\right]_{0}=0.04 \mathrm{~mol} \cdot \mathrm{l}^{-1}, V_{g}=8.3 \cdot 10^{-3} \mathrm{l} \cdot \mathrm{s}^{-1}, V_{r . m .}=0.01 \mathrm{l}$

The nature of the kinetic curves of 1-phenylethan-1-ol and 1-phenylethyl acetate accumulation highlights an interesting regularity: with the increase of ozone concentration in the system, the maximum concentration of non-acylated alcohol decreases and the acylated one increases at the concentration to
$5.2 \cdot 10^{-4} \mathrm{~mol} \cdot \mathrm{l}^{-1}$. In conditions when manganese, even at minimal ozone concentrations, is predominantly in oxidized form, the increase of the ozone concentration cannot affect the acceleration of the velocity of acylated alcohol formation according to the reaction scheme (6-8). 


\section{A. Galstyan, A. Bushuiev, K. Skorokhod, A. Krasylnikova, M. Zhurba}

\section{Conclusions}

It is ascertained that the catalyst - manganese (II) acetate plays a decisive role in achieving the desired oxidation selectivity according to the ethyl group of ethylbenzene and its substituents in the ratio $\left[\mathrm{ArCH}_{2} \mathrm{CH}_{3}\right]_{0}:\left[\mathrm{Mn}(\mathrm{OAc})_{2}\right]_{0}=1: 0,1$. It has been shown that in the conditions of catalytic oxidation, ozone plays the role of the generator of the oxidized form of metal, which takes part in the oxidation initiation reaction, and the decrease in temperature to $288 \mathrm{~K}$ contributes to the prevailing formation of the corresponding acetophenone.

Based on the conducted research, the optimal conditions for the production of acetophenone were determined and the method of synthesis of this product was proposed.

\section{References}

1. Carter M..I., J. Mol. Catal. A: Chem, 2003, 200, 191. https://doi.org/10.1016/S1381-1169(03)00098-0.

2. Hermans I., Spier E., Neuenschwander U., Top. Catal, 2009, 52, 1162. doi: 10.1007/s11244-009-9268-3

3. Shaabani A., Mirzaei P., Lee D. G., Catalysis Letter, 2004, 97, $119 . \quad$ doi: 10.1023/B:CATL. 0000038572.73523.bd

4. Choudhary V. R., Indurkar J. R., Narkhede V. S., Jha R., Journal of Catalysis, 2004, 227, 257. doi: 10.1016/j.jcat.2004.07.017

5. Galstyan G. A., Tyupalo N. F., Galstyan A. G., Zhidkofaznoe kataliticheskoe okislenie aromaticheskikh soedinenij ozonom. Lugansk: VNU, 2009.

6. Pan H., Li S., Shu M., Cui Q., Zhao Z., Science Asia, 2018, 44, 212. doi: 10.2306/scienceasia15131874.2018.44.212.
7. Hwang K. Ch., Sagadevan A., Sustainable P. Ch., Hwang K. K., Green Chemistry, 2019, 22, 2. doi: $10.1039 /$ C9GC02095K

8. Potapenko E. V., Andreev P. Y., Isayenko I. P., Voprosy Khimii i Khimicheskoi Tekhnologii, 2018, 4, 43. https:/udhtu.edu.ua/public/userfiles/file/VHHT/2018/4/Po tapenko.pdf

9. Vojtkevich S. A., 865 dushisty`kh veshhestv dlya parfyumerii i by`ovoj khimii. M, Pishhevaya promy`shlennost, 1994.

10. Passet B. V., Vorob`eva V. L. Tekhnologiya khimiko-farmaczevticheskikh preparatov. M., Medicina, 1976.

11. Nesmeyanov A.N., Nesmeyanov N.A. Nachala organicheskoj khimii, kn. 2. M., Nauka, 1970.

12. Lebedev N. N. Khimiya i tekhnologiya osnovnogo organicheskogo i neftekhimicheskogo sinteza. Uchebnik dlya vuzov. 4-e izd. M., Khimiya, 1988.

13. Petukhov A. A., Tajmasov I. R., Shajkhutdinov R. Z., Vestnik Kazanskogo tekhnologicheskogo universiteta, 2013, 16, 89. https://cyberleninka.ru/article/ n/okislenie-atsetofenona-v-prisutstvii-benzoynoy-kisloty/

14. Emanue'l' N.M. Uspekhi khimii organicheskikh perekisny’kh soedinenij i autookisleniya. M., Khimiya, 1969.

15. Bailey P. S. Ozonation in organic chemistry. Vol. 2. Nonolefinic Compounds. N.-Y., Academic Press, 1982.

16. E`manue`l` N. M., Denisov E. T., Majzus Z. K. Czepny’e reakczii okisleniya uglevodorodov $\mathrm{V}$ zhidkoj faze. M., Nauka, 1965.

17.Galstyan A., Marshalok H., Galstyan T., Kuleshova T., Marshalok O.: Przemysł Chemiczny, 2019, 98, 1475. doi: 10.15199/62.2019.9.30.

18. Galstyan A., Galstyan G., Timoshyna L., Chemistry and Chemical Technology, 2018, 12, 341. https://doi.org/10.23939/chcht12.03.341

\section{А. Г. Галстян ${ }^{1,2}$, А. С. Бушуєв ${ }^{1}$, К. С. Скороход ${ }^{2}$, А. О. Красильникова ${ }^{1}$, М. С. Журба ${ }^{1}$ \\ ${ }^{1}$ Д3 “Луганський державний медичний університет” \\ ${ }^{2}$ Східноукраїнський національний університет імені Володимира Даля aggaalst@gmail.com}

\section{КІНЕТИКА ТА ПРОДУКТИ ОКИСНЕННЯ ЕТИЛБЕНЗЕНУ ТА ЙОГО ЗАМЩЩЕНИХ ОЗОНОМ В ОЦТОВІЙ КИСЛОТІ}

На основі отриманих кінетичних закономірностей та суміші продуктів реакції окиснення етилбензену з озоном в оцтовій кислоті розроблено наукові основи технології синтезу ацетофенону. Показано, що в умовах озонування у присутності ацетату марганцю (II) можна направляти окиснення переважно за етильною групою субстрату з утворенням ароматичних продуктів. Вивчено технологічні параметри та встановлено оптимальні умови для реалізації процесу. Отримані експериментальні та теоретичні результати дозволили запропонувати новий низькотемпературний маловідходний метод виробництва ацетофенону, який забезпечус ефективність процесу завдяки м'яким умовам окиснення (288 К, атмосферний тиск) та зменшенню токсичних відходів. Технологія може бути альтернативою існуючим методам синтезу ароматичних кетонів.

Ключові слова: етилбензен, ацетофенон, каталізатор, кінетика, окиснення, озон. 